\title{
Proteome analysis of Lactobacillus helveticus H9 during growth in skim milk
}

\author{
Y. F. Chen, ${ }^{*} \dagger^{1}$ W. J. Zhao, ${ }^{*}{ }^{1}$ R. N. Wu, $† \S$ Z. H. Sun, ${ }^{\star} \dagger$ W. Y. Zhang, ${ }^{*}$ J. C. Wang, ${ }^{*}$ M. Bilige, ${ }^{*}$ and H. P. Zhang ${ }^{*} \dagger^{2}$ \\ *Key Laboratory of Dairy Biotechnology and Engineering, Ministry of Education, Inner Mongolia Agricultural University, Huhhot, P. R. China, \\ 010018 \\ †Synergetic Innovation Center of Food Safety and Nutrition, Jiangnan University, Wuxi, P. R. China, 214122 \\ ¥The Institute of Products Quality Inspection and Research Inner Mongolia Autonomous Region, Huhhot, P. R. China, 010070 \\ $\S$ College of Food Science, Shenyang Agricultural University, Shenyang, P. R. China, 110866
}

\section{ABSTRACT}

Lactobacillus helveticus $\mathrm{H} 9$ was isolated from traditionally fermented yak milk in Tibet (China) with the ability to produce the antihypertensive peptides Val-Pro-Pro (VPP) and Ile-Pro-Pro (IPP) during milk fermentation. To understand the changes in the protein expression of L. helveticus $\mathrm{H} 9$, proteome analysis was performed at 3 different growth stages, lag phase $(\mathrm{pH}$ 6.1), log phase ( $\mathrm{pH} 5.1$ ), and stationary phase ( $\mathrm{pH} 4.5)$ using 2-dimensional electrophoresis (2-DE). Further analysis showed that 257 differential protein spots were found and 214 protein spots were identified using matrix-assisted laser desorption/ionization time-of-flight mass spectrometry (MALDI-TOF/MS). The cellular functions of the differentially expressed proteins were complex. Interestingly, the proteolytic system-related proteins aminopeptidase $\mathrm{N}(\mathrm{PepN})$, aminopeptidase $\mathrm{E}$ (PepE), endopeptidase O2 (PepO2), and oligopeptide transport system permease protein (OppC) were observed only on the maps of $\mathrm{pH} 5.1$ and $\mathrm{pH} 4.5$, which was consistent with the presence of angiotensin I-converting enzyme (ACE)-inhibitory pepti'des VPP and IPP during these 2 growth stages (log phase and stationary phase). These results, combined with a previous study of gene expression of the proteolytic system, led us to conclude that the Opp transport system, pepE, and pepO2 are likely related to the production of ACEinhibitory peptides.

Key words: proteomics, Lactobacillus helveticus H9, proteolytic system

\section{INTRODUCTION}

Lactobacillus helveticus is widely distributed in dairy fermentation worldwide (Sadat-Mekmene et al., 2013; Strahinic et al., 2013). Some isolates, such as Lactobacillus helveticus strains DPC4571, CP790, LBK16H,

Received June 24, 2014.

Accepted August 28, 2014.

${ }^{1}$ Yongfu Chen and Wenjing Zhao contributed equally to this paper.

${ }^{2}$ Corresponding author: hepingdd@vip.sina.com and CNRZ32, are regarded as probiotic bacteria and have been used in functional fermentation production due to their high proteolytic activity and production of bioactive peptides (Nakamura et al., 1995; Yamamoto et al., 1999; Kilpia et al., 2007). Therefore, much attention has been focused on L. helveticus in China recently (Pan et al., 2005; Sun et al., 2009; Tian et al., 2009; Zhang et al., 2013). Lactobacillus helveticus H9 was isolated from traditionally fermented yak milk in Tibet by our group (Chen et al., 2014). Previous experiments demonstrated that L. helveticus $\mathrm{H} 9$ has higher proteolytic activity than other isolated Lactobacillus strains when incubated in skim milk and, during the fermentation process of skim milk, it produces the antihypertensive peptides Val-Pro-Pro (VPP) and IlePro-Pro (IPP), which can reduce blood pressure.

Thus, in L. helveticus, not only is the essential amino nitrogen produced for growth in milk through the proteolytic system, but the proteolytic system probably also contributes to the formation of VPP and IPP. Developments in molecular technology provide the tools to further study the mechanisms involved in L. helveticus proteolytic systems.

Generally, proteolytic systems involved in lactic acid bacteria contain 2 enzyme parts, an extracellular Prt serine proteinase that can degrade casein and the main milk globular protein to oligopeptides, and peptidases that are capable of hydrolyzing oligopeptides to peptides. Lactobacillus helveticus strains exhibit great biodiversity of 1-4 cell-envelope proteinase $(C E P)$ gene, including prtH1, prtH2, prtH3, prtM, and prtP (Yamamoto et al., 1994; Scolari et al., 2006; Broadbent et al., 2011). Moreover, Manso et al. (2005) reported that 5 peptidases (PepN, PepC, PepDA, PepV, PepQ) and 2 endopeptidases (PepO and PepO3) were observed in stationary growing cells of $L$. helveticus ITG LH1 using 2-dimensional electrophoresis (2-DE).

Great improvements in our understanding of proteolytic systems have been made by comparative genomic analysis. The complete genome sequences of $L$. helveticus (with its characteristic rapid lysis and high proteolytic activity) show many genes responsible for key 
metabolic functions such as proteolysis, lipolysis, and cell lysis (Callanan et al., 2008; Prajapati et al., 2011; Zhao et al., 2011; Tompkins et al., 2012). Cremonesi et al. (2013) hypothesized a pathway for VPP and IPP formation in L. helveticus, which was based on microarray analysis of gene expression in L. helveticus CM4 of the proteolytic enzymes involved in the processing of VPP and IPP by Wakai et al. (2012). The proteolytic action consists of the hydrolysis of $\beta$-casein by cell-wall proteinase; then, the generated peptides are transferred into the cell by oligopeptide transporter, where endopeptidases, such as PepO2, $\mathrm{PepC}$, and PepX, can act on at the C- and N-terminal sequences to produce VPP and IPP. Besides protease PrtM, proteins involved in Opp peptide transport system and the intracellular peptidases PepE, PepN, and PepQ were found in the probiotic strain $L$. helveticus M92 when cultivated in de Man, Rogosa, and Sharpe medium using SDS-PAGE and liquid chromatography-tandem MS analysis (Beganovíc et al., 2013). However, more data are needed.

In the current study, proteome analysis of L. helveticus $\mathrm{H} 9$ cultivated in skim milk was performed using 2-DE and matrix-assisted laser desorption/ionization time-of-flight mass spectrometry (MALDI-TOF/ MS). Protein expression profiles were compared in 3 different growth stages in an attempt to reveal comprehensive metabolism changes in L. helveticus H9 during fermentation of skim milk.

\section{MATERIALS AND METHODS}

\section{Bacterial Strain, Medium, and Growth Conditions}

The L. helveticus strain H9 (LABCC IMAU60208) was isolated from traditionally fermented yak milk in Tibet (China) and was preserved in the Key Laboratory of Dairy Biotechnology and Engineering, Ministry of Education, Inner Mongolia Agricultural University, China. Strain H9 was incubated in sterilized skim milk for $48 \mathrm{~h}$ at $37^{\circ} \mathrm{C}$. The $\mathrm{pH}$ value was measured using a pHSJ-3F pH meter (Leici, Shanghai, China). The concentrations of VPP and IPP were determined using liquid chromatography-electrospray ionization mass spectrometry (LC-ESI-MS/MS), and the analyses were performed in triplicate (Chen et al., 2010). Samples of the bacterial cells were collected in the lag, $\log$ and stationary phase during growth in milk for 1 , 5 , and 7 to $8 \mathrm{~h}$, and the corresponding $\mathrm{pH}$ values were 6.1, 5.1, and 4.5.

\section{Preparation of the Protein Extraction}

Two different methods were used to collect the bacterial cells as described by Wang et al. (2013). Before cur- dling at $\mathrm{pH} 6.1$, cultures were harvested by centrifugation at $3,000 \times g$ for $7 \mathrm{~min}$ at $4^{\circ} \mathrm{C}$. Then, $0.5 \mathrm{M}$ ice-cold EDTA was added to the precipitate and centrifuged at $3,000 \times g$ for $7 \mathrm{~min}$ at $4^{\circ} \mathrm{C}$. The precipitate was then washed with $0.5 \mathrm{M}$ ice-cold EDTA in $30 \%$ (vol/vol) icecold ethanol, centrifuged, and washed again with $30 \%$ ice-cold ethanol and centrifuged at 3,000 $\times g$ for $7 \mathrm{~min}$ at $4^{\circ} \mathrm{C}$. The isolated cells were frozen in liquid nitrogen and preserved at $-80^{\circ} \mathrm{C}$. After curdling at $\mathrm{pH} 5.1$ and $\mathrm{pH} 4.5$, cultures were harvested by centrifugation at $200 \times g$ for $10 \mathrm{~min}$ at $4^{\circ} \mathrm{C}$, and the corresponding supernatants was filtered and centrifuged at $3,000 \times g$ for $10 \mathrm{~min}$ at $4^{\circ} \mathrm{C}$ to collect the cells. The cell pellets were frozen in liquid nitrogen and preserved at $-80^{\circ} \mathrm{C}$.

A solution of $250 \mathrm{~m} M$ sucrose (pH 7.0) and $10 \mathrm{~m} M$ Tris was added to the frozen bacterial pellets and centrifuged at $6,000 \times g$ for $10 \mathrm{~min}$ at $4^{\circ} \mathrm{C}$, and the collected precipitate was suspended in lysis buffer, which contained $8 M$ urea, $2 M$ thiourea, $0.5 \% 3$-[(3-cholamidopropyl) dimethylammonio]-1-propanesulfonate (CHAPS; wt/ vol), $2 \%$ ampholytes, $1 \%$ dithiothreitol, and $1 \mathrm{mM}$ phenylmethylsulfonyl fluoride. Subsequently, $50 \mu \mathrm{g} /$ $\mathrm{mL}$ of DNaseI was added to the solution, which was then sonicated with a sonicator (Hielscher, Stuttgart, Germany) 4 times (ultrasonic: $30 \mathrm{~s}$, pulse duration: 30 $\mathrm{s}$ ), and the proteins in the supernatant were obtained through centrifugation at $14,000 \times g$ for $30 \mathrm{~min}$ at $4^{\circ} \mathrm{C}$ and preserved at $-80^{\circ} \mathrm{C}$. The protein concentrations were quantified using the Bradford protein assay.

\section{Two-Dimensional Electrophoresis}

The protein extract was first separated using firstdimension isoelectric focusing (IEF). Seventeen-centimeter immobilized $\mathrm{pH}$ gradient (IPG) strips, with a nonlinear range of $\mathrm{pH} 4$ to 7 (Bio-Rad, Hercules, CA), were rehydrated in buffer containing $8 M$ urea, $2 M$ thiourea, $0.5 \%$ CHAPS (wt/vol), $1 \%$ dithiothreitol, $0.52 \%$ ( vol/vol) IPG buffer, and $0.02 \%$ bromophenol blue for $12 \mathrm{~h}$. A total of $0.8 \mathrm{~g}$ of the protein was diluted with the above buffer to a volume of $170 \mu \mathrm{L}$ and loaded on the IPG strips. The IEF was performed in a Multiphor II Electrophoresis system (Bio-Rad, Hercules, CA) according to the following conditions: $0-500 \mathrm{~V}$ for $500 \mathrm{~V} \cdot \mathrm{h}, 500 \mathrm{~V}$ for $2,500 \mathrm{~V} \cdot \mathrm{h}, 500-3,500 \mathrm{~V}$ for 10,000 $\mathrm{V} \cdot \mathrm{h}, 3,500 \mathrm{~V}$ for $50,000 \mathrm{~V} \cdot \mathrm{h}$, and $3,500-500 \mathrm{~V}$ for 8,000 $\mathrm{V} \cdot \mathrm{h}$.

Following the IEF program, the strips were equilibrated immediately in 2 steps in buffers I and II, respectively, which contained $50 \mathrm{~m} M$ Tris-HCL (pH 6.8), $6 \mathrm{M}$ urea, $30 \%$ glycerol, $2 \%$ SDS, $0.02 \%$ bromophenol blue, and $2 \%$ dithiothreitol (buffer I) or $2.5 \%$ iodoacetamide (buffer II); the equilibration time for each step was $15 \mathrm{~min}$. 
The equilibrated strips were loaded on a $12 \%$ SDSPAGE gel, and the second-dimension SDS-PAGE was performed in a Protean II xi Cell (Bio-Rad) at $15 \mathrm{~mA} /$ gel and then at $45 \mathrm{~mA} / \mathrm{gel}$. The gels were silver stained and scanned using the Powerlook 2100XL apparatus (UMAX, Taiwan).

The images of the gels were assayed with PDQuest 7.0 software (Bio-Rad). After the automatic detection of the matched protein spots, manual collection was performed using the Edit Spot Tools and Match Tools from Bio-Rad. Three gels were produced for each growth stage, and the protein spots present on at least 2 of the gels were used for the subsequent assays. The protein spots were identified as being differential if they met the following conditions: the average ratio of the spot intensities showed at least a 2 -fold difference (ratio $\geq 2.0$ or $\leq 0.5$ ) in the 3 growth stages, and the protein spots were produced only at the $\mathrm{pH} 6.1(1 \mathrm{~h})$ growth stage (lag phase) or at both the $\mathrm{pH} 5.1(5 \mathrm{~h})$ and $\mathrm{pH}$ $4.5(7-8 \mathrm{~h})$ growth stages (log and stationary phases, respectively).

\section{Mass Spectrometry Analyses}

The differential protein spots were excised manually from the 2-DE gels and washed 3 times, destained 3 times (15 min each) with a mixture (equal volume) of $30 \mathrm{~m} M$ potassium ferricyanide and $100 \mathrm{~m} M$ sodium thiosulfate, dehydrated $5 \mathrm{~min}$ with $30 \mu \mathrm{L}$ of acetonitrile $(100 \%)$, and incubated in $8 \mu \mathrm{L}$ of a trypsin solution $(0.05 \mathrm{mg} / \mathrm{mL})$ for $16 \mathrm{~h}$ at $37^{\circ} \mathrm{C}$. This reaction solution was also used for the mass spectrometry analysis.

An equal volume of the above reaction solution was mixed with a matrix solution, containing $25 \mathrm{mM}$ ammonium bicarbonate, $0.1 \%$ trifluoroacetic acid, $50 \%$ acetonitrile, and $10 \mathrm{mg} / \mathrm{ml}$ of $\alpha$-cyano-4-hydroxycinnamic acid, and was used for the mass spectrum. The peptide mass fingerprinting was performed on a 4700 Proteomics Analyzer (Applied Biosystems, Foster City, CA). All of the differential proteins were identified using MALDITOF/MS.

The GPS Explorer v3.5 software (Applied Biosystems) was used to assay the mass spectrum data under the following parameters: the peptide fragment mass tolerance was $\pm 0.1 \mathrm{Da}$, the fixed modification was carbamidomethylation, and the variable modification was oxidation. The complete genome sequence of $L$. helveticus H9 (LBH CP002427) was used as the database to search the proteins. Generally, protein identification was regarded as successful when the protein score confidence interval (MALDI-TOF) was greater than $95 \%$. If more than one protein was successfully identified for one protein spot, we selected the protein with the higher score.
Theoretical molecular weights and isoelectric points of the identified proteins and all of the genome-annotated proteins were calculated using the ExPASy ProtParam tool (us.expasy.org/tools/pi_tool.html). The functional classifications of the proteins were also analyzed through clusters of orthologous groups (COG; http:// www.ncbi.nlm.nih.gov/COG/).

\section{RESULTS AND DISCUSSION}

\section{Generation Information of L. helveticus H9 on 2-DE Maps}

The theoretical 2-DE map of L. helveticus H9 showed that the protein points were bimodally distributed between an isoelectric point (pI) of 4 and 10 (Figure 1). Similar to other lactobacilli, the major proteins were observed between $\mathrm{p} I 4$ and 7 . Hence, the present study constructed 2-DE maps of L. helveticus H9 during growth in milk using IPG pI 4 to 7 (Figure 2).

The study further compared the proteome profiles of $L$. helveticus at 3 growth stages. The numbers of corresponding detected protein spots on maps were ap-

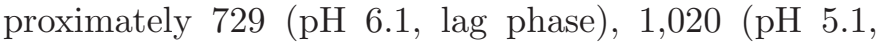
log phase), and 925 ( $\mathrm{pH} 4.5$, stationary phase; Figure 2 ). The obvious variation between $\mathrm{pH} 6.1, \mathrm{pH} 5.1$, and $\mathrm{pH} 4.5$ was probably related to the beginning growth of bacteria and the different methods used in protein extraction. We identified 214 differentially expressed protein spots using MALDI-TOF/MS, including spots that were only observed in one growth stage, as well as protein spots that were up- or downregulated between $\mathrm{pH} 6.1$ and $\mathrm{pH} 5.1$, and between $\mathrm{pH} 6.1$ and $\mathrm{pH} 4.5$, respectively (Table 1 and Supplementary Figure S1 and Tables S1 and S2; http://dx.doi.org/10.3168/jds.20148520). In detail, 35 protein spots were observed only

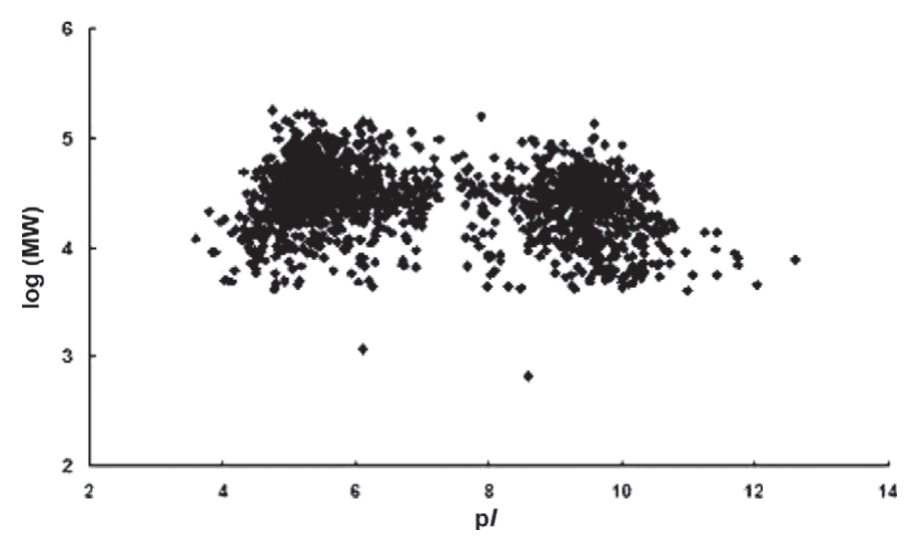

Figure 1. The theoretical 2-dimensional electrophoresis (2-DE) map of Lactobacillus helveticus H9. MW = molecular weight; $\mathrm{p} I=$ isoelectric point. 



Figure 2. Two-dimensional electrophoresis (2-DE) maps of Lactobacillus helveticus H9 during growth in skim milk at 3 different stages and the differential expressed proteins found in the study: (AA) 2-DE map of lag phase (pH 6.1) and the protein spots expressed only on the map of $\mathrm{pH}$ 6.1; (BB) 2-DE map of log phase ( $\mathrm{pH} 5.1$ ) and the protein spots also expressed at the growth stages of stationary phase (pH 4.5) and the protein spots both expressed at the growth stages of $\mathrm{pH} 4.5$; (BC) 2-DE map of stationary phase (pH 4.5) and the protein spots also expressed at the growth stages of $\log$ phase ( $\mathrm{pH} 5.1) . \mathrm{M}=$ molecular weight; $\mathrm{p} I=$ isoelectric point. 
on the map of pH 6.1 (Supplementary Table S1), and 150 protein spots were found on the maps of $\mathrm{pH} 5.1$ and 4.5 (Table 1), as well as 29 up- or downregulated protein spots between $\mathrm{pH} 6.1$ and both $\mathrm{pH} 5.1$ and 4.5 (Supplementary Table S2), respectively.

Furthermore, several proteins were identified in multiple spots and, in most cases, with different forms. Posttranslational modifications appeared to be common in L. helveticus $\mathrm{H} 9$, such as elongation factor Ts (spots 2159, 4303, 4324, 4423), serine hydroxymethyltransferase (spots 4121, 6623, 7236, 7509), and phosphoglycerate kinase (spots 2305, 2416, 2512, 3419, 3421, 3407). Posttranslational modifications are known to play an important role in eukaryotes, whereas less is known about their role in bacterial physiology (Yuan et al., 2006).

\section{Differentially Expressed Proteins in L. helveticus H9}

Based on the analysis of 214 identified protein spots, the metabolism involved in the growth of $L$. helveticus H9 in skim milk at different stages is complex. Based on the COG results, cellular roles of both theoretical and identified proteins are presented in Figure 3. Proteins belonging to translation, ribosomal structure, and biogenesis comprised the majority of identified proteins, followed by proteins related to nucleotide transport and metabolism, carbohydrate transport and metabolism, and amino acid transport and metabolism.

Considering the detection of ACE-inhibitory peptides VPP and IPP only in the log phase ( $\mathrm{pH} 5.1$ ) and stationary phase ( $\mathrm{pH} \mathrm{4.5;} \mathrm{Table} \mathrm{2),} \mathrm{the} \mathrm{following}$ discussion focuses particularly on the proteins found on the maps of both $\mathrm{pH} 4.5$ and $\mathrm{pH} 5.1$, but not on the map of $\mathrm{pH} 6.1$ (Table 1).

\section{Proteins Related to the Proteolytic System}

Interestingly, proteins involved in the proteolytic system were not expressed at $\mathrm{pH} 6.1$ (Supplementary Tables S1 and S2; http://dx.doi.org/10.3168/jds.20148520). However, 4 proteins related to the proteolytic system were found on the maps of $\mathrm{pH} 5.1$ and 4.5 (Table 1): aminopeptidase N (PepN, spot 1909) and aminopeptidase E (PepE, spots 1512 and 2509), endopeptidase O2 (PepO2, spots 2804 and 2806) and oligopeptide transport system permease protein $(\mathbf{O p p C}$, spots 8227 and 8314). The function of aminopeptidase is to hydrolyze AA from the $\mathrm{N}$ terminus of a polypeptide chain. General aminopeptidases include PepN and aminopeptidase C (PepC); PepN has wide substance specificity and plays important roles in the hydrolysis of peptides derived from milk proteins. Previous studies demonstrated that PepN was important for the growth of L. helveticus in milk (Christensen and Steele, 2003) and that PepN was related to the inhibitory activity of ACE in fermented milk (Kilpi et al., 2007). Endopeptidase $\mathrm{E}$ is a cysteine proteinase that may play a role in peptide hydrolysis during cheese ripening (Fenster et al., 1997). The results were similar to those described by that also found PepE and PepN in L. helveticus M92 when cultivated in de Man, Rogosa, and Sharpe medium using SDS-PAGE and LC-MS/MS analysis (Beganovíc et al., 2013).

The endopeptidase pepO2, which is a post-proline endopeptidase, has a different substrate specificity compared with endopeptidase O (PepO). It has a preference for small, uncharged AA and AA with a proline residue on the carboxyl-side bond. It may play a central role in reducing the bitterness of cheese (Sridhar et al., 2005). Casein-derived peptides have been observed to contain relatively large amounts of Pro; thus, PepO2 may play an important role in hydrolyzing the peptides derived from milk proteins, which has been reported by Cremonesi et al. (2013).

The oligopeptide transport system (Opp) transports the oligopeptides derived from the hydrolysis of milk proteins to the intracellular space; the system includes the oligopeptide-binding protein OppA, 2 transmembrane proteins (OppB and $\mathrm{OppC}$ ), and the nucleotidebinding proteins $\mathrm{OppD}$ and $\mathrm{OppF}$. We identified one component of the Opp system, OppC, revealing that the Opp system exists in L. helveticus H9 and is expressed at growth stages $\mathrm{pH} 5.1$ and $\mathrm{pH} 4.5$, and could be involved in transport of oligopeptides. Previous research showed that the cell wall-associated proteinase (PrtP) and the Opp transport system are necessary for the growth of the strain in milk because they participate in the first step of casein hydrolysis and in the utilization of generated peptides (Tynkkynen et al., 1993; Juillard et al., 1995a,b). Although proteinase PrtP was not identified in the present study, expression of prtP was found upregulated in the log and stationary phases, and prtM was upregulated in log phase and then downregulated in stationary phase (Zhang et al., 2014). Additionally, PepE, PepO2, and $O p p C$ were highly expressed in both $\log$ and stationary phases. This might indicate that the Opp transport system, PepE, and PepO2 are essential for growth of the strain L. helveticus $\mathrm{H} 9$ in milk to produce ACE-inhibitory peptides from milk proteins.

In addition, we identified several proteins related to amino acid transport and metabolism, such as aspartate aminotransferase (Ast, spot 5522), serine hydroxymethyltransferase (GlyA, spots 4121, 6623, 7236, 7509), dihydrodipicolinate synthase (DapA, spot 3314) and glutamine synthetase (GlnA, spot 7217). Among the proteins, GlyA catalyzes the conversion of serine into glycine, which can then provide a methyl group for 
Table 1. Proteins expressed on 2-dimensional electrophoresis (2-DE) gels in the stationary phase ( $\mathrm{pH}$ 4.5) and log phase (pH 5.1) of Lactobacillus helveticus H9 cultured in milk, but not expressed in the lag phase $(\mathrm{pH} 6.1)^{1}$

\begin{tabular}{|c|c|c|c|c|c|c|c|}
\hline No. & Spot & Protein name & $\begin{array}{l}\text { Protein } \\
\text { MW (Da) }\end{array}$ & $\begin{array}{l}\text { Protein } \\
\quad \mathrm{p} I\end{array}$ & $\begin{array}{l}\text { Peptide } \\
\text { count }\end{array}$ & COG & $\begin{array}{c}\text { Fold-change } \\
\text { pH } 4.5 / \\
\text { pH } 5.1\end{array}$ \\
\hline 1 & 1512 & Aminopeptidase E & $49,365.7$ & 5.2 & 6 & AA transport and metabolism & 1.014 \\
\hline 2 & 1621 & Peptidase $\mathrm{T}$ & 47,168 & 4.8 & 9 & AA transport and metabolism & 1.200 \\
\hline 3 & 1909 & Aminopeptidase $\mathrm{N}$ & $95,821.5$ & 4.8 & 32 & AA transport and metabolism & 0.589 \\
\hline 4 & 2509 & Aminopeptidase E & $49,365.7$ & 5.2 & 15 & AA transport and metabolism & 0.762 \\
\hline 5 & 4121 & Serine hydroxymethyltransferase & 45,107 & 5.8 & 5 & AA transport and metabolism & 2.085 \\
\hline 6 & 5522 & Aspartate aminotransferase & $42,525.9$ & 5.5 & 7 & AA transport and metabolism & 0.729 \\
\hline 7 & 6623 & Serine hydroxymethyltransferase & 45,107 & 5.8 & 5 & AA transport and metabolism & 0.599 \\
\hline 8 & 6808 & $\begin{array}{l}\text { 5-Methyltetrahydropteroyltriglutamate-homocysteine } \\
\text { methyltransferase }\end{array}$ & $87,450.5$ & 5.9 & 22 & AA transport and metabolism & 0.567 \\
\hline 9 & 7217 & Glutamine synthetase & 50,856 & 5.1 & 6 & AA transport and metabolism & 0.314 \\
\hline 10 & 7236 & Serine hydroxymethyltransferase & 45,107 & 5.8 & 4 & AA transport and metabolism & 0.457 \\
\hline 11 & 7509 & Serine hydroxymethyltransferase & 45,107 & 5.8 & 15 & AA transport and metabolism & 0.368 \\
\hline 12 & 8227 & $\begin{array}{l}\text { Oligopeptide ABC superfamily ATP binding cassette } \\
\text { transporter permease protein }\end{array}$ & 120,288 & 7.3 & 12 & AA transport and metabolism & 0.833 \\
\hline 13 & 3314 & Dihydrodipicolinate synthase & $34,522.7$ & 5 & 8 & AA transport and metabolism & 0.773 \\
\hline 14 & 8314 & $\begin{array}{l}\text { Oligopeptide ABC superfamily ATP binding cassette } \\
\text { transporter permease protein }\end{array}$ & 120,288 & 7.3 & 19 & AA transport and metabolism & 0.763 \\
\hline 15 & 1318 & Citrate lyase $\beta$-chain & 32,180 & 4.8 & 15 & Carbohydrate transport and metabolism & 0.963 \\
\hline 16 & 1620 & Enolase 1 & $46,895.2$ & 4.8 & 11 & Carbohydrate transport and metabolism & 0.360 \\
\hline 17 & 2305 & Phosphoglycerate kinase & $44,476.3$ & 5.5 & 7 & Carbohydrate transport and metabolism & 1.684 \\
\hline 18 & 2416 & Phosphoglycerate kinase & $44,476.3$ & 5.5 & 7 & Carbohydrate transport and metabolism & 0.906 \\
\hline 19 & 2512 & Phosphoglycerate kinase & $44,476.3$ & 5.5 & 5 & Carbohydrate transport and metabolism & 1.235 \\
\hline 20 & 3318 & 6-Phosphogluconolactonase & 160,504 & 7.3 & 13 & Carbohydrate transport and metabolism & 0.411 \\
\hline 21 & 3419 & Phosphoglycerate kinase & $44,476.3$ & 5.5 & 5 & Carbohydrate transport and metabolism & 0.531 \\
\hline 22 & 3421 & Phosphoglycerate kinase & $44,476.3$ & 5.5 & 6 & Carbohydrate transport and metabolism & 0.701 \\
\hline 23 & 3615 & Phosphoglucomutase & $64,364.7$ & 5.4 & 13 & Carbohydrate transport and metabolism & 1.656 \\
\hline 24 & 7224 & Galactose-1-phosphate uridylyltransferase & $55,814.3$ & 5.7 & 5 & Carbohydrate transport and metabolism & 0.398 \\
\hline 25 & 7501 & Galactose-1-phosphate uridylyltransferase & $55,814.3$ & 5.7 & 24 & Carbohydrate transport and metabolism & 0.581 \\
\hline 26 & 3815 & Pyruvate kinase & 103,272 & 5.1 & 15 & Carbohydrate transport and metabolism & 0.394 \\
\hline 27 & 5317 & UTP-glucose-1-phosphate uridylyltransferase & $33,634.7$ & 6.1 & 6 & Cell envelope biogenesis, outer membrane & 0.697 \\
\hline 28 & 6717 & Glutamine-fructose-6-phosphate transaminase (Isomerizing) & $66,131.2$ & 5.5 & 10 & Cell envelope biogenesis, outer membrane & 1.879 \\
\hline 29 & 7220 & UDP-glucose 4-epimerase (fragment) & $36,391.5$ & 6.1 & 8 & Cell envelope biogenesis, outer membrane & 2.440 \\
\hline 30 & 7223 & UDP-glucose 4-epimerase (fragment) & $36,391.5$ & 6.1 & 7 & Cell envelope biogenesis, outer membrane & 1.509 \\
\hline 31 & 7229 & UTP-glucose-1-phosphate uridylyltransferase & 33,878 & 6.7 & 4 & Cell envelope biogenesis, outer membrane & 0.724 \\
\hline 32 & 7323 & UTP-glucose-1-phosphate uridylyltransferase & $33,634.7$ & 6.1 & 16 & Cell envelope biogenesis, outer membrane & 0.231 \\
\hline 33 & 7325 & UDP-glucose 4-epimerase (fragment) & $36,391.5$ & 6.1 & 3 & Cell envelope biogenesis, outer membrane & 0.479 \\
\hline 34 & 7608 & UDP-N-acetylmuramoyl-l-alanyl-d-glutamyl-l-lysine ligase & $58,157.9$ & 5.8 & 15 & Cell envelope biogenesis, outer membrane & 0.310 \\
\hline 35 & 7615 & UDP-N-acetylmuramoyl-l-alanyl-d-glutamyl-l-lysine ligase & $58,157.9$ & 5.8 & 18 & Cell envelope biogenesis, outer membrane & 0.237 \\
\hline 36 & 8315 & UDP-glucose 4-epimerase (fragment) & $36,391.5$ & 6.1 & 17 & Cell envelope biogenesis, outer membrane & 1.085 \\
\hline 37 & 8316 & UDP-glucose 4-epimerase (fragment) & $36,391.5$ & 6.1 & 14 & Cell envelope biogenesis, outer membrane & 0.372 \\
\hline 38 & 8317 & UDP-glucose 4-epimerase (fragment) & $36,391.5$ & 6.1 & 15 & Cell envelope biogenesis, outer membrane & 1.602 \\
\hline 39 & 8318 & UDP-glucose 4-epimerase (fragment) & $36,391.5$ & 6.1 & 20 & Cell envelope biogenesis, outer membrane & 1.460 \\
\hline 40 & 4225 & NAD-dependent epimerase/dehydratase & $23,699.2$ & 5.3 & 4 & Cell envelope biogenesis, outer membrane & 0.531 \\
\hline 41 & 5417 & Probable tRNA sulfurtransferase & $45,866.8$ & 6.4 & 8 & Coenzyme metabolism & 0.663 \\
\hline 42 & 6414 & Probable tRNA sulfurtransferase & $45,866.8$ & 6.4 & 12 & Coenzyme metabolism & 0.380 \\
\hline 43 & 7218 & Bifunctional protein folD & $30,762.4$ & 7.8 & 8 & Coenzyme metabolism & 0.333 \\
\hline 44 & 7231 & Bifunctional protein folD & $30,762.4$ & 7.8 & 8 & Coenzyme metabolism & 0.479 \\
\hline 45 & 8213 & Bifunctional protein folD & $30,762.4$ & 7.8 & 9 & Coenzyme metabolism & 0.217 \\
\hline 46 & 8223 & Bifunctional protein folD & $30,762.4$ & 7.8 & 8 & Coenzyme metabolism & 2.782 \\
\hline
\end{tabular}


Table 1 (Continued). Proteins expressed on 2-dimensional electrophoresis (2-DE) gels in the stationary phase (pH 4.5) and log phase (pH 5.1) of Lactobacillus helveticus H9 cultured in milk, but not expressed in the lag phase $(\mathrm{pH} 6.1)^{1}$

\begin{tabular}{|c|c|c|c|c|c|c|c|}
\hline No. & Spot & Protein name & $\begin{array}{l}\text { Protein } \\
\text { MW (Da) }\end{array}$ & $\begin{array}{l}\text { Protein } \\
\mathrm{p} I\end{array}$ & $\begin{array}{l}\text { Peptide } \\
\text { count }\end{array}$ & COG & $\begin{array}{c}\text { Fold-change } \\
\text { pH 4.5/ } \\
\text { pH } 5.1\end{array}$ \\
\hline 47 & 8225 & Bifunctional protein folD & $30,762.4$ & 7.8 & 9 & Coenzyme metabolism & 1.334 \\
\hline 48 & 8418 & Probable tRNA sulfurtransferase & $45,866.8$ & 6.4 & 5 & Coenzyme metabolism & 0.238 \\
\hline 49 & 8525 & Nicotinate phosphoribosyltransferase & 120,210 & 9.1 & 14 & Coenzyme metabolism & 1.023 \\
\hline 50 & 4116 & Transposase IS607 family & $84,479.1$ & 8.7 & 9 & DNA replication, recombination, and repair & 1.056 \\
\hline 51 & 4230 & Transposase IS607 family & $84,479.1$ & 8.7 & 10 & DNA replication, recombination, and repair & 3.593 \\
\hline 52 & 4611 & DNA replication protein DnaD & $85,946.7$ & 5.4 & 17 & DNA replication, recombination, and repair & 0.164 \\
\hline 53 & 2219 & Glycerol-3-phosphate dehydrogenase $[\mathrm{NAD}(\mathrm{P})+]$ & $37,267.2$ & 5.4 & 6 & Energy production and conversion & 0.850 \\
\hline 54 & 6224 & Citrate lyase ligase & $39,249.1$ & 5.6 & 6 & Energy production and conversion & 0.171 \\
\hline 55 & 9613 & Pyridine nucleotide-disulphide oxidoreductase family protein & $49,741.9$ & 7.1 & 10 & Energy production and conversion & 0.325 \\
\hline 56 & 3019 & $\begin{array}{l}\text { Pyridoxine } 5 \text { '-phosphate oxidase V related favin-nucleotide- } \\
\text { binding protein }\end{array}$ & $14,679.7$ & 6.3 & 4 & General function prediction only & 0.800 \\
\hline 57 & 3020 & $\begin{array}{l}\text { Pyridoxine } 5^{\prime} \text {-phosphate oxidase V related favin-nucleotide- } \\
\text { binding protein }\end{array}$ & $14,679.7$ & 6.3 & 4 & General function prediction only & 0.626 \\
\hline 58 & 4217 & Permease & $69,668.1$ & 7.3 & 9 & General function prediction only & 1.513 \\
\hline 59 & 5523 & ATP-grasp superfamily protein & $50,645.4$ & 5.8 & 5 & General function prediction only & 0.459 \\
\hline 60 & 7235 & Cystathionine $\beta$-synthase (CBS) domain protein & $26,519.7$ & 6.2 & 10 & General function prediction only & 0.593 \\
\hline 61 & 8712 & Methionyl-tRNA synthetase & 108,138 & 5.6 & 11 & General function prediction only & 0.225 \\
\hline 62 & 1149 & Acetyl-CoA biotin carboxyl carrier & $17,377.8$ & 4.9 & 7 & Lipid metabolism & 1.890 \\
\hline 63 & 1152 & Acetyl-CoA biotin carboxyl carrier & $17,377.8$ & 4.9 & 5 & Lipid metabolism & 1.022 \\
\hline 64 & 3221 & Enoyl-[acyl-carrier-protein] reductase (NADH) & 27,186 & 5.5 & 6 & Lipid metabolism & 0.773 \\
\hline 65 & 4223 & Enoyl-[acyl-carrier-protein] reductase (NADH) & 27,186 & 5.5 & 7 & Lipid metabolism & 0.519 \\
\hline 66 & 5528 & Phosphate acyltransferase & $36,032.8$ & 5.5 & 6 & Lipid metabolism & 3.834 \\
\hline 67 & 6013 & Carrier protein & 13,471 & 5.7 & 4 & Lipid metabolism & 0.986 \\
\hline 68 & 3218 & Phosphoribosylformylglycinamidine synthase 1 & $24,733.5$ & 5.1 & 4 & Nucleotide transport and metabolism & 5.143 \\
\hline 69 & 5217 & Phosphoribosylaminoimidazolecarboxamide formyltransferase & $79,401.4$ & 6.6 & 6 & Nucleotide transport and metabolism & 1.997 \\
\hline 70 & 5415 & Phosphoribosylamine-glycine ligase & $46,386.4$ & 5.4 & 13 & Nucleotide transport and metabolism & 0.651 \\
\hline 71 & 6219 & Adenylate kinase (fragment) & $21,098.8$ & 6 & 8 & Nucleotide transport and metabolism & 0.327 \\
\hline 72 & 6520 & Inosine-5-monophosphate dehydrogenase & $36,822.8$ & 5.8 & 10 & Nucleotide transport and metabolism & 0.462 \\
\hline 73 & 7113 & Purine/pyrimidine phosphoribosyltransferase & $20,374.8$ & 5.6 & 5 & Nucleotide transport and metabolism & 0.786 \\
\hline 74 & 7114 & Purine/pyrimidine phosphoribosyltransferase & $20,374.8$ & 5.6 & 5 & Nucleotide transport and metabolism & 1.074 \\
\hline 75 & 7238 & Guanylate kinase & $23,030.9$ & 5.7 & 4 & Nucleotide transport and metabolism & 0.521 \\
\hline 76 & 7613 & $\begin{array}{l}\text { Bifunctional GMP synthase/glutamine amidotransferase } \\
\text { protein }\end{array}$ & $58,939.6$ & 5.7 & 18 & Nucleotide transport and metabolism & 0.643 \\
\hline 77 & 7614 & Formate-tetrahydrofolate ligase (fragment) & $51,279.6$ & 5.9 & 7 & Nucleotide transport and metabolism & 0.502 \\
\hline 78 & 8111 & Purine/pyrimidine phosphoribosyltransferase & $20,374.8$ & 5.6 & 4 & Nucleotide transport and metabolism & 1.748 \\
\hline 79 & 8112 & Adenine phosphoribosyltransferase & $20,124.6$ & 5.8 & 9 & Nucleotide transport and metabolism & 6.373 \\
\hline 80 & 8419 & Phosphoribosylaminoimidazole carboxylase ATPase subunit & $42,597.7$ & 6.3 & 4 & Nucleotide transport and metabolism & 0.286 \\
\hline 81 & 8528 & Phosphoribosylaminoimidazole carboxylase ATPase subunit & $42,597.7$ & 6.3 & 7 & Nucleotide transport and metabolism & 0.193 \\
\hline 82 & 8530 & Phosphoribosylaminoimidazole carboxylase ATPase subunit & $42,597.7$ & 6.25 & 9 & Nucleotide transport and metabolism & 0.560 \\
\hline 83 & 8716 & Phosphoribosylaminoimidazolecarboxamide formyltransferase & $79,401.4$ & 6.6 & 21 & Nucleotide transport and metabolism & 0.238 \\
\hline 84 & 9208 & Adenylate kinase (fragment) & $21,098.8$ & 6 & 8 & Nucleotide transport and metabolism & 0.192 \\
\hline 85 & 9506 & Phosphoribosylaminoimidazole carboxylase ATPase subunit & $42,597.7$ & 6.3 & 8 & Nucleotide transport and metabolism & 0.643 \\
\hline 86 & 9507 & Phosphoribosylaminoimidazole carboxylase ATPase subunit & $42,597.7$ & 6.3 & 5 & Nucleotide transport and metabolism & 0.115 \\
\hline 87 & 9804 & Phosphoribosylaminoimidazolecarboxamide formyltransferase & $79,401.4$ & 6.6 & 17 & Nucleotide transport and metabolism & 0.369 \\
\hline 88 & 6322 & Ribose-phosphate pyrophosphokinase & 36,519 & 5.7 & 11 & Nucleotide transport and metabolism & 0.525 \\
\hline 89 & 7221 & Ribose-phosphate pyrophosphokinase 1 & $35,600.7$ & 6.5 & 8 & Nucleotide transport and metabolism & 1.138 \\
\hline 90 & 7222 & Ribose-phosphate pyrophosphokinase 1 & $35,600.7$ & 6.5 & 8 & Nucleotide transport and metabolism & 0.478 \\
\hline 91 & 7322 & Ribose-phosphate pyrophosphokinase & 36,519 & 5.7 & 12 & Nucleotide transport and metabolism & 0.394 \\
\hline 92 & 8216 & Ribose-phosphate pyrophosphokinase 1 & $35,600.7$ & 6.5 & 7 & Nucleotide transport and metabolism & 0.195 \\
\hline
\end{tabular}




\begin{tabular}{|c|c|c|c|c|c|c|c|}
\hline No. & Spot & Protein name & $\begin{array}{l}\text { Protein } \\
\text { MW (Da) }\end{array}$ & $\begin{array}{l}\text { Protein } \\
\quad \mathrm{p} I\end{array}$ & $\begin{array}{l}\text { Peptide } \\
\text { count }\end{array}$ & $\mathrm{COG}$ & $\begin{array}{l}\text { Fold-change } \\
\text { pH 4.5/ } \\
\text { pH } 5.1\end{array}$ \\
\hline 93 & 2621 & Trigger factor & $49,428.4$ & 5.1 & 9 & $\begin{array}{l}\text { Posttranslational modification, protein turnover } \\
\text { chaperones }\end{array}$ & 0.465 \\
\hline 94 & 2720 & Trigger factor & $49,428.5$ & 5.11 & 8 & $\begin{array}{l}\text { Posttranslational modification, protein turnover } \\
\text { chaperones }\end{array}$ & 1.051 \\
\hline 95 & 2721 & $60 \mathrm{kDa}$ chaperonin & $57,603.2$ & 5.2 & 15 & $\begin{array}{l}\text { Posttranslational modification, protein turnover } \\
\text { chaperones }\end{array}$ & 0.527 \\
\hline 96 & 2804 & Endopeptidase O2 & $73,619.4$ & 5 & 14 & $\begin{array}{l}\text { Posttranslational modification, protein turnover } \\
\text { chaperones }\end{array}$ & 6.998 \\
\hline 97 & 2806 & Endopeptidase O2 & $73,619.4$ & 5 & 12 & $\begin{array}{l}\text { Posttranslational modification, protein turnover } \\
\text { chaperones }\end{array}$ & 0.376 \\
\hline 98 & 3731 & $60 \mathrm{kDa}$ chaperonin & $57,603.2$ & 5.2 & 8 & $\begin{array}{l}\text { Posttranslational modification, protein turnover } \\
\text { chaperones }\end{array}$ & 0.989 \\
\hline 99 & 5319 & Predicted: similar to caseinolytic peptidase $\mathrm{X}$ & $46,811.6$ & 6 & 10 & $\begin{array}{l}\text { Posttranslational modification, protein turnover } \\
\text { chaperones }\end{array}$ & 0.898 \\
\hline 100 & 7324 & $60 \mathrm{kDa}$ chaperonin & $57,603.2$ & 5.2 & 13 & $\begin{array}{l}\text { Posttranslational modification, protein turnover } \\
\text { chaperones }\end{array}$ & 1.302 \\
\hline 101 & 2415 & Central glycolytic gene regulator & $82,055.7$ & 5.5 & 15 & Transcription & 0.882 \\
\hline 102 & 2422 & Central glycolytic gene regulator & $82,055.7$ & 5.5 & 6 & Transcription & 1.895 \\
\hline 103 & 3316 & Central glycolytic gene regulator & $82,055.7$ & 5.5 & 12 & Transcription & 0.636 \\
\hline 104 & 3919 & DNA-directed RNA polymerase subunit $\beta$ & 135,777 & 5.5 & 15 & Transcription & 0.212 \\
\hline 105 & 5212 & Central glycolytic gene regulator & $82,055.7$ & 5.5 & 8 & Transcription & 2.230 \\
\hline 106 & 5222 & YyaA-like protein & $31,851.9$ & 6.9 & 7 & Transcription & 0.570 \\
\hline 107 & 112 & 50 S ribosomal protein L10 & $18,617.8$ & 4.8 & 8 & Translation, ribosomal structure and biogenesis & 0.875 \\
\hline 108 & 308 & $30 \mathrm{~S}$ ribosomal protein $\mathrm{S} 2$ & $28,736.7$ & 4.8 & 14 & Translation, ribosomal structure and biogenesis & 0.303 \\
\hline 109 & 313 & $30 \mathrm{~S}$ ribosomal protein $\mathrm{S} 2$ & $28,736.7$ & 4.8 & 14 & Translation, ribosomal structure and biogenesis & 0.982 \\
\hline 110 & 1212 & Elongation factor $\mathrm{P}$ & $21,045.7$ & 5.5 & 4 & Translation, ribosomal structure and biogenesis & 0.611 \\
\hline 111 & 1414 & Elongation factor $\mathrm{Tu}$ & $44,762.97$ & 4.99 & 8 & Translation, ribosomal structure and biogenesis & 0.835 \\
\hline 112 & 1626 & Elongation factor $\mathrm{Tu}$ & 44,763 & 5 & 11 & Translation, ribosomal structure and biogenesis & 3.007 \\
\hline 113 & 1627 & Elongation factor $\mathrm{Tu}$ & 44,763 & 5 & 8 & Translation, ribosomal structure and biogenesis & 0.863 \\
\hline 114 & 2159 & Elongation factor Ts & $37,710.4$ & 5.4 & 6 & Translation, ribosomal structure and biogenesis & 0.645 \\
\hline 115 & 2316 & Elongation factor $\mathrm{Tu}$ & 44,763 & 5 & 14 & Translation, ribosomal structure and biogenesis & 2.037 \\
\hline 116 & 2417 & Elongation factor $\mathrm{Tu}$ & 44,763 & 5 & 16 & Translation, ribosomal structure and biogenesis & 1.120 \\
\hline 117 & 2420 & Elongation factor $\mathrm{Tu}$ & 44,763 & 5 & 12 & Translation, ribosomal structure and biogenesis & 0.814 \\
\hline 118 & 2421 & Elongation factor $\mathrm{Tu}$ & 44,763 & 5 & 17 & Translation, ribosomal structure and biogenesis & 2.077 \\
\hline 119 & 2508 & Elongation factor $\mathrm{G}$ & $76,703.8$ & 5 & 6 & Translation, ribosomal structure and biogenesis & 0.934 \\
\hline 120 & 2520 & Elongation factor $\mathrm{P}$ & $66,022.6$ & 4.9 & 8 & Translation, ribosomal structure and biogenesis & 0.476 \\
\hline 121 & 2622 & Elongation factor $\mathrm{Tu}$ & 44,763 & 5 & 10 & Translation, ribosomal structure and biogenesis & 0.631 \\
\hline 122 & 2630 & Elongation factor $\mathrm{Tu}$ & 44,763 & 5 & 4 & Translation, ribosomal structure and biogenesis & 0.430 \\
\hline 123 & 2809 & Glycyl-tRNA synthetase $\beta$ subunit & $78,396.1$ & 5.1 & 17 & Translation, ribosomal structure and biogenesis & 0.778 \\
\hline 124 & 3224 & TrmH family RNA methyltransferase & $28,281.6$ & 5.3 & 6 & Translation, ribosomal structure and biogenesis & 0.637 \\
\hline 125 & 3723 & Alanine-tRNA ligase & 100,466 & 5.4 & 11 & Translation, ribosomal structure and biogenesis & 0.256 \\
\hline 126 & 3810 & Proline-tRNA ligase & $63,289.4$ & 5.4 & 8 & Translation, ribosomal structure and biogenesis & 0.608 \\
\hline 127 & 4303 & Elongation factor $\mathrm{Ts}$ & $37,710.4$ & 5.4 & 13 & Translation, ribosomal structure and biogenesis & 1.898 \\
\hline 128 & 4324 & Elongation factor Ts & $37,710.4$ & 5.4 & 4 & Translation, ribosomal structure and biogenesis & 0.625 \\
\hline 129 & 4421 & Sua5 family translation factor & $36,992.4$ & 5.5 & 5 & Translation, ribosomal structure and biogenesis & 2.779 \\
\hline 130 & 4423 & Elongation factor Ts & $37,710.4$ & 5.4 & 13 & Translation, ribosomal structure and biogenesis & 0.603 \\
\hline 131 & 5416 & $\begin{array}{l}\text { Aspartyl/glutamyl-tRNA(Asn/Gln) amidotransferase subunit } \\
\text { B }\end{array}$ & $48,933.9$ & 6.2 & 13 & Translation, ribosomal structure and biogenesis & 1.355 \\
\hline 132 & 6009 & $30 \mathrm{~S}$ ribosomal protein $\mathrm{S} 4$ & $23,372.2$ & 9.8 & 8 & Translation, ribosomal structure and biogenesis & 0.028 \\
\hline 133 & 6014 & $30 \mathrm{~S}$ ribosomal protein $\mathrm{S} 4$ & $23,372.2$ & 9.8 & 8 & Translation, ribosomal structure and biogenesis & $\begin{array}{l}0.227 \\
\text { Continued }\end{array}$ \\
\hline
\end{tabular}


other synthesis pathways (Derzelle et al., 2005); GlnA is a key enzyme that allows a strain to grow in milk cultures (Hornbaek et al., 2004).

\section{Proteins Related to Carbohydrate Metabolism and Peptidoglycan Assembly}

The proteins related to carbohydrate metabolism contained enolase (Eno, spot 1620), phosphoglycerate kinase (Pgk, spots 2305, 2416, 2512, 3419, 3421, 3407), and pyruvate kinase (Pyk, spots 6715, 3815, 5711, 5713, 3711) (Table 1, Supplementary Tables S1 and S2; http://dx.doi.org/10.3168/jds.2014-8520). Moreover, citrate lyase was expressed at both the $\mathrm{pH} 5.1$ and $\mathrm{pH}$ 4.5 growth stages (Table 1) and may be related to the accumulation of lactate in the fermentation process. Previous research revealed that citrate lyase could be induced under acidic conditions, making cells resistant to the inhibitory effects of the fermentation product (lactate; Martín et al., 2004). Two galactose degradation pathways have been identified in the lactic acid bacteria: the Leloir pathway (which converts galactose to glucose-6-phosphate) and the tagatose-6-phosphate pathway (which converts galactose to glyceraldehyde-3-phosphate and dihydroxyacetone phosphate; Poolman, 1993; de Vos, 1996). Several proteins that participate in galactose metabolism were also detected, including uridine diphosphate (UDP)-glucose1-uridylyltransferase (GalU, spots 5317, 7229, 7323), UDP-glucose-4-epimerase (GalE, spots 7220, 7223, 7325, 8615, 8616, 8617, 8618), glucosephosphomutase (Pgm, spots 3615, 4609), and $\beta$-galactosidase (lacL, spot 4704), which revealed that L. helveticus H9 could utilize galactose through either of the 2 pathways. The expression of these proteins can increase the level of UDP-glucose, which is the precursor of glycolipids and teichoic acids. Because previous research has shown that glycolipids are related to the stability of the cell membrane, our results indicated that the expression of these proteins at the 2 growth stages $(\mathrm{pH} 5.1$ and $\mathrm{pH}$ 4.5) may be related to the strengthening of the cell wall, thus leading to the strong resistance of the strain.

Table 2. Angiotensin I-converting enzyme inhibitory (ACEI) activity and the concentrations of VPP and IPP of Lactobacillus helveticus H9 grown in skim milk at different growth stages ${ }^{1}$

\begin{tabular}{lccc}
\hline $\mathrm{pH}$ & ACEI $(\%)$ & $\mathrm{VPP}(\mu M)$ & $\mathrm{IPP}(\mu M)$ \\
\hline $6.1 \pm 0.01$ & $20.9 \pm 2.7$ & $\mathrm{ND}^{2}$ & $\mathrm{ND}$ \\
$5.1 \pm 0.03$ & $62.4 \pm 3.7$ & $0.469 \pm 0.019$ & $0.195 \pm 0.024$ \\
$4.5 \pm 0.00$ & $79.6 \pm 3.6$ & $2.923 \pm 0.037$ & $1.732 \pm 0.083$ \\
\hline
\end{tabular}

${ }^{1}$ VPP $=$ Val-Pro-Pro; IPP = Ile-Pro=Pro.

${ }^{2} \mathrm{ND}=$ not detected. 




Figure 3. Schematic of the cellular role categories (COG; clusters of orthologous groups) of the theoretical (open bars) and identified (black bars) proteins on a 2-dimensional electrophoresis (2-DE) gel in Lactobacillus helveticus H9. C = energy production and conversion; D = cell division, chromosome partitioning; $\mathrm{E}=$ amino acid transport and metabolism; $\mathrm{F}=$ nucleotide transport and metabolism; $\mathrm{G}=$ carbohydrate transport and metabolism; $\mathrm{H}=$ coenzyme metabolism; $\mathrm{I}=$ lipid and metabolism; $\mathrm{J}=$ translation, ribosomal structure and biogenesis; $\mathrm{K}=$ transcription; $\mathrm{L}=\mathrm{DNA}$ replication, recombination, and repair; $\mathrm{M}=$ cell envelope biogenesis, outer membrane; $\mathrm{N}=$ cell motility and secretion; $\mathrm{O}=$ posttranslational modification, protein turnover, chaperones; $\mathrm{P}=$ inorganic ion transport and metabolism; $\mathrm{Q}=$ secondary metabolites biosynthesis, transport and catabolism; $\mathrm{R}=$ general function prediction only; $\mathrm{S}=$ function unknown; $\mathrm{T}=$ signal transduction mechanisms; $\mathrm{U}$ = intracellular trafficking, secretion, and vesicular transport; and $\mathrm{V}=$ defense mechanisms.

Two key enzymes, UDP-N-acetylmuramoylalanine D-glutamate ligase (MurD, spots 6504, 6511) and UDP-MurNac-tripeptide synthetase (MurE, spots 7603, $7608,7615)$ involved in the synthesis of a cytoplasmic peptidoglycan precursor, were identified in Table 1 and Supplementary Table S2 (http://dx.doi.org/10.3168/ jds.2014-8520). Peptidoglycans are important components of the cell wall, thus, the expression of MurD and MurE might indicate the cell division during the growth or an increase of the peptidoglycan content.

\section{Proteins Related to Nucleotide Transport and Metabolism}

We identified 10 protein spots related to nucleotide transport and metabolism. The enzymes were grouped into purine biosynthesis pathways (Table 1 and Supplementary Table S2; http://dx.doi.org/10.3168/jds.20148520), and included phosphoribosylamine-glycine ligase (PurD, spot 5415), phosphoribosylaminoimidazole carboxamide formyltransferase/IMP cyclohydrolase (PurH, spots 5217, 8716, 9804, 8615), phosphoribosylaminoimidazole carboxylase NCAIR mutase subunit (PurK, spots 8419, 8528, 8530, 9506, 9507) and phosphoribosylformylformylglycinamidine synthase (PurL, spot 3218); pyrimidine metabolism were found in Supplementary Table S1 (http://dx.doi.org/10.3168/ jds.2014-8520), including CTP synthase (PyrG, spot
6612), uracil phosphoribosyltransferase/pyrimidine operon regulatory protein (pyrR, spot 9101), uracil phosphoribosyltransferase (Upp, spot 9205), cytidylate kinase (Cmk, spot 9206), and Ser/Thr phosphatase family protein (spot 9611).

Lactobacilli can produce nucleotides through de novo biosynthesis or acquire them from the surroundings (Kilstrup et al., 2005). Milk contains a substantial amount of the pyrimidine precursor orotate but is very poor in purine bases (Beyer et al., 2003). Recent studies also showed that proteins related to the nucleotide metabolism pathway were expressed in the lag stage of Lactococcus lactis and Lactobacillus casei Zhang (Beyer et al., 2003; Gitton et al., 2005; Wang et al., 2013). The findings might indicate faster metabolism of pyrimidine than purine in L. helveticus $\mathrm{H} 9$.

The current study also identified formic acid tetrahydrofolic acid synthetase (Fhs, spot 7614), which can produce a cofactor of the biosynthesis of inosine monophosphate (IMP), the intermediate product of purine metabolism. Brejning et al. (2003) demonstrated that Fhs was induced in the absence of purine using a proteomic method. Gitton et al. (2005) and Smeianov et al. (2007) revealed that the expression of the protein Fhs and the corresponding gene fhs were regulated when the strain was grown in a milk culture. Our results agreed with these conclusions, showing that the absence of purine bases in milk. 


\section{Proteins Related to Translation and Transcription}

Proteins related to the synthesis of DNA and RNA, such as transfer (t)RNA synthetases (aspartyl/glutamyl-tRNA, arginyl-tRNA synthetase, glycyl-tRNA synthetase $\beta$ subunit glutamyl-tRNA synthetase, leucyl-tRNA synthetase, and methionyl-tRNA synthetase) were found on all 3 maps, whereas transcription elongation factors (EF-T; EF-Tu, EF-G, and EF-P) were identified on maps of $\mathrm{pH} 5.1$ and $\mathrm{pH} 4.5$ (Table 1 ). The primary function of elongation factors is to deliver aminoacyl-tRNA to the ribosome, and research has revealed that they may be related to protein folding or stress protection. In the current study, EF-Tu was expressed at growth stages $\mathrm{pH} 5.1$ and $\mathrm{pH} 4.5$, which might indicate that EF-Tu has a protective role in the synthesis of new proteins or it might be related to the tolerance of the strain.

\section{Ribosomal Proteins and Stress Proteins}

We identified 5 different ribosomal proteins: $30 \mathrm{~S}$ ribosomal protein $\mathrm{S} 2$ (RpsB, spots 1210, 308, 313, 2315), 50S ribosomal protein L10 (RplJ, spot 112), 30S ribosomal protein S4 (RpsD, spots 6009, 6014), 50S ribosomal protein L1 (RplA, spots 7112, 7215, 7216) and 50S ribosomal protein L32 (RpmF, spot 8713) in the study. Ribosomal proteins are the main component of the ribosome, which is important for protein biosynthesis. They have also been regarded as indicators of heat stress and cold stress (Kawarai et al., 2007). Previous research revealed that ribosomal proteins participate in the growth process of bacteria (VanBogelen and Neidhardt, 1990). In our research, we found that most of ribosomal proteins were expressed in growth stages $\mathrm{pH} 5.1$ and $\mathrm{pH} 4.5$, showing their importance in growth of the strain.

Molecular chaperones or stress proteins play a crucial role in the folding, assembly, transport, and degradation of large biological molecules, especially under different stress conditions (acidic, alkaline, oxidizing, heat or cold stress). In the present study, 4 types of stress proteins, GroEL (spots 2721, 3731, 7324), DnaK (spot 2708), DnaD (spot 4611), and $33 \mathrm{kDa}$ chaperonin (spot 7206), were found. Previous research revealed that the expression of these proteins was regulated in the stationary phase (Haandrikman et al., 1989). In general, when any strain is grown until the stationary phase, nutrients are depleted, leading to the production of stress proteins or molecular chaperone proteins, which then help the cells adapt to the culture conditions (Van De Guchte et al., 2002). Meanwhile, when the strain starts to grow, the chaperone proteins may be induced to activate the expression of proteins, such as DnaK (spot 2708) in the present study (Table 1).

\section{Other Proteins}

We identified several proteins related to fatty acid biosynthesis, including S-malonyltransferase (FabD, spot 4211), enoyl-[acyl-carrier-protein] reductase (FabL, spots 3221, 4223), 3R-hydroxyacyl-acyl-carrierprotein dehydratase (FabZ, spot 6013), biotin carboxyl carrier protein of acetyl-CoA carboxylase (AccB, spots 1149, 1152), biotin carboxylase (AccC, spot 5512), and glycerol-3-phosphate acyltransferase (PlsX, spot 5528). We also identified proteins related to coenzyme metabolism: probable tRNA sulfurtransferase (spots 5417 , 6414, 8418, 9404), bifunctional protein (FolD, spots $7218,7231,8213,8223,8225)$, nicotinate phosphoribosyltransferase (PncB, spots 8518, 8525), dihydrofolate reductase (FolA, spot 9112), and methionine adenosyltransferase (MetK, spot 3613), as well as some proteins with general or unknown functions. Additional research will be required to understand their physiological roles.

Overall, the growth response of strain L. helveticus H9 in milk is complicated. It needs all of the systems to be involved coordinately. During the fermentation of yogurt, ACE-inhibitory peptides were produced increasingly more in the stationary phase than in the log phase. The study showed that the process of VPP and IPP in L. helveticus H9 might be directly connected to PepN, PepO2, and OppC. Therefore, considering hypertension is now the most common chronic diseases in the modern circumstance, the production of ACEinhibitory peptides VPP and IPP by L. helveticus $\mathrm{H} 9$ might have promising applications; for example, in the treatment of high blood pressure.

\section{ACKNOWLEDGMENTS}

This research was supported by the National Natural Science Foundation of China (Beijing, China; Grant No.31101315), the Hi-Tech Research and Development Program of China (863 Planning, Beijing, China; Grant No. 2011AA100902), the Special Fund for Agroscientific Research in the Public Interest (Beijing, China; Grant No. 201303085, 201203009), and China Agriculture Research System (Beijing, China; Grant No. CARS-37).

\section{REFERENCES}

Beganovíc, J., K. Blazenka, A. L. Pavunc, K. Uroic, P. Dzidara, and J. Suskovic. 2013. Proteolytic activity of probiotic strain Lactobacillus helveticus M92. Anaerobe 20:58-64. 
Beyer, N. H., P. Roepstorff, K. Hammer, and M. Kilstrup. 2003. Proteome analysis of the purine stimulon from Lactococcus lactis. Proteomics 3:786-797.

Brejning, J., L. Jespersen, and N. Arneborg. 2003. Genome-wide transcriptional changes during the lag phase of Saccharomyces cerevisiae. Arch. Microbiol. 179:278-294.

Broadbent, J. R., H. Cai, R. L. Larsen, J. E. Hughes, D. L. Welker, V. G. De Carvalho, T. A. Tompkins, Y. Ardö, F. Vogensen, A. De Lorentiis, M. Gatti, E. Neviani, and J. L. Steele. 2011. Genetic diversity in proteolytic enzymes and amino acid metabolism among Lactobacillus helveticus strains. J. Dairy Sci. 94:4313-4328.

Callanan, M., P. Kaleta, J. O'Callaghan, O. O'Sullivan, K. Jordan, O. McAuliffe, A. Sangrador-Vegas, L. Slattery, G. F. Fitzgerald, T. Beresford, and R. P. Ross. 2008. Genome sequence of Lactobacillus helveticus, an organism distinguished by selective gene loss and insertion sequence element expansion. J. Bacteriol. 190:727-735.

Chen, Y., W. Liu, J. Xue, J. Yang, X. Chen, Y. Shao, L. Kwok, M. Bilige, L. Mang, and H. Zhang. 2014. Angiotensin-converting enzyme inhibitory activity of Lactobacillus helveticus strains from traditional fermented dairy foods and antihypertensive effect of fermented milk of strain H9. J. Dairy Sci. 97:6680-6692. http:// dx.doi.org/10.3168/jds.2014-7962.

Chen, Y., Z. Wang, X. Chen, Y. Liu, H. Zhang, and T. Sun. 2010. Identification of angiotensin I-converting enzyme inhibitory peptides from koumiss, a traditional fermented mare's milk. J. Dairy Sci. 93:884-892.

Christensen, J. E., and J. L. Steele. 2003. Impaired growth rates in milk of Lactobacillus helveticus peptidase mutants can be overcome by use of amino acid supplements. J. Bacteriol. 185:3297-3306.

Cremonesi, P., S. Chessa, and C. Bianca. 2013. Genome sequence and analysis of Lactobacillus helveticus. Front. Microbiol. 3:435.

de Vos, W. M. 1996. Metabolic engineering of sugar catabolism in lactic acid bacteria. Antonie van Leeuwenhoek 70:223-242.

Derzelle, S., A. Bolotin, M. Y. Mistou, and F. Rul. 2005. Proteome analysis of Streptococcus thermophilus grown in milk reveals pyruvate formate-lyase as the major upregulated protein. Appl. Environ. Microbiol. 71:8597-8605.

Fenster, K. M., K. L. Parkin, and J. L. Steele. 1997. Characterization of a thiol-dependent endopeptidase from Lactobacillus helveticus CNRZ32. J. Bacteriol. 179:2529-2533.

Gitton, C., M. Meyrand, J. Wang, C. Caron, A. Trubuil, A. Guillot, and M. Y. Mistou. 2005. Proteomic signature of Lactococcus lactis NCDO763 cultivated in milk. Appl. Environ. Microbiol. 71:7152-7163.

Haandrikman, A. J., J. Kok, H. Laan, S. Soemitro, A. M. Ledeboer, W. N. Konings, and G. Venema. 1989. Identification of a gene required for maturation of an extracellular lactococcal serine proteinase. J. Bacteriol. 171:2789-2794.

Hornbaek, T., M. Jakobsen, J. Dynesen, and A. K. Nielsen. 2004. Global transcription profiles and intracellular $\mathrm{pH}$ regulation measured in Bacillus licheniformis upon external $\mathrm{pH}$ upshifts. Arch. Microbiol. 182:467-474.

Juillard, V., H. Laan, E. R. Kunji, C. M. Jeronimus-Stratingh, A. P. Bruins, and W. N. Konings. 1995a. The extracellular PI-type proteinase of Lactococcus lactis hydrolyzes beta-casein into more than one hundred different oligopeptides. J. Bacteriol. 177:3472-3478.

Juillard, V., D. Le Bars, E. R. Kunji, W. N. Konings, J. C. Gripon, and J. Richard. 1995b. Oligopeptides are the main source of nitrogen for Lactococcus lactis during growth in milk. Appl. Environ. Microbiol. 61:3024-3030.

Kawarai, T., S. Furukawa, H. Ogihara, and M. Yamasaki. 2007. Mixed-species biofilm formation by lactic acid bacteria and rice wine yeasts. Appl. Environ. Microbiol. 73:4673-4676.

Kilpi, E. E. R., M. M. Kahala, J. L. Steele, A. M. Pihlanto, and V. V. Joutsjoki. 2007. Angiotensin I-converting enzyme inhibitory activity in milk fermented by wild-type and peptidase-deletion derivatives of Lactobacillus helveticus CNRZ32. Int. Dairy J. 17:976-984.

Kilstrup, M., K. Hammer, P. Ruhdal Jensen, and J. Martinussen. 2005. Nucleotide metabolism and its control in lactic acid bacteria. FEMS Microbiol. Rev. 29:555-590.
Manso, M. A., J. Leonil, M. Piot, and V. Gagnaire. 2005. Isolation and characterisation of a Lactobacillus helveticus ITG LH1 peptidaserich sub-proteome. Int. J. Food Microbiol. 105:119-129.

Martín, M. G., P. D. Sender, S. Peiru, D. de Mendoza, and C. Magni. 2004. Acid-inducible transcription of the operon encoding the citrate lyase complex of Lactococcus lactis Biovar diacetylactis CRL264. J. Bacteriol. 186:5649-5660.

Nakamura, Y., N. Yamasee, K. Sakai, A. Okubo, S. Vamazak, and T. Takano. 1995. Purification and characterization of angiotensin I-converting enzyme inhibitors from sour milk. J. Dairy Sci. 78:777-783

Pan, D. D., Y. K. Luo, and M. Tanokura. 2005. Antihypertensive peptides from skimmed milk hydrolysate digested by cell-free extract of Lactobacillus helveticus JCM1004. Food Chem. 91:123-129.

Poolman, B. 1993. Energy transduction in lactic acid bacteria. FEMS Microbiol. Rev. 12:125-147.

Prajapati, J. B., C. D. Khedkar, J. Chitra, S. Suja, V. Mishra, V. Sreeja, R. K. Patel, V. B. Ahir, V. D. Bhatt, M. R. Sajnani, S. J. Jakhesara, P. G. Koringa, and C. G. Joshi. 2011. Wholegenome shotgun sequencing of an Indian origin Lactobacillus helveticus strain, MTCC5463, with probiotic potential. J. Bacteriol. 193:4282-4283.

Sadat-Mekmene, L., R. Richoux, L. Aubert-Frogerais, M. N. Madec, C. Corre, M. Piot, J. Jardin, S. le Feunteun, S. Lortal, and V. Gagnaire. 2013. Lactobacillus helveticus as a tool to change proteolysis and functionality in Swiss-type cheeses. J. Dairy Sci. 96:1455-1470

Scolari, G., M. Vescovo, C. Zacconi, and F. Vescovi. 2006. Extraction and partial characterization of proteolytic activities from the cell surface of Lactobacillus helveticus Zuc2. J. Dairy Sci. 89:38003809.

Smeianov, V. V., P. Wechter, J. R. Broadbent, J. E. Hughes, B. T. Rodriguez, T. K. Christensen, Y. Ardo, and J. L. Steele. 2007. Comparative high-density microarray analysis of gene expression during growth of Lactobacillus helveticus in milk versus rich culture medium. Appl. Environ. Microbiol. 73:2661-2672.

Sridhar, V. R., J. E. Hughes, D. L. Welker, J. R. Broadbent, and J. L. Steele. 2005. Identification of endopeptidase genes from the genomic sequence of Lactobacillus helveticus CNRZ32 and the role of these genes in hydrolysis of model bitter peptides. Appl. Environ. Microbiol. 71:3025-3032.

Strahinic, I., J. Lozo, A. Terzic-Vidojevic, D. Fira, M. Kojic, N. Golic, J. Begovic, and L. Topisirovic. 2013. Technological and probiotic potential of BGRA43, a natural isolate of Lactobacillus helveticus. Front. Microbiol. 4:2

Sun, T. S., S. P. Zhao, H. K. Wang, C. K. Cai, Y. F. Chen, and H. P. Zhang. 2009. ACE-inhibitory activity and gamma-aminobutyric acid content of fermented skim milk by Lactobacillus helveticus isolated from Xinjiang koumiss in China. Eur. Food Res. Technol. 228:607-612.

Tian, J. Y., D. D. Pan, and Y. X. Guo. 2009. Optimization of enzymatic hydrolysis technology of casein by proteinases from Lactobacillus helveticus for ACE-inhibitory peptide production. Food Sci. 11:170-174. (In Chinese).

Tompkins, T. A., G. Barreau, and J. R. Broadbent. 2012. Complete genome sequence of Lactobacillus helveticus R0052, a commercial probiotic strain. J. Bacteriol. 194:6349.

Tynkkynen, S., G. Buist, E. Kunji, J. Kok, B. Poolman, G. Venema and A. Haandrikman. 1993. Genetic and biochemical characterization of the oligopeptide transport system of Lactococcus lactis. J. Bacteriol. 175:7523-7532.

van De Guchte, M., P. Serror, C. Chervaux, T. Smokvina, S. D. Ehrlich, and E. Maguin. 2002. Stress responses in lactic acid bacteria. Antonie van Leeuwenhoek 82:187-216.

VanBogelen, R. A., and F. C. Neidhardt. 1990. Ribosomes as sensors of heat and cold shock in Escherichia coli. Proc. Natl. Acad. Sci. USA $87: 5589-5593$.

Wakai, T., N. Yamaguchi, M. Hatanaka, Y. Nakamura, and N. Yamamoto. 2012. Repressive processing of antihypertensive peptides, Val-Pro-Pro and Ile-Pro-Pro, in Lactobacillus helveticus fermented milk by added peptides. J. Biosci. Bioeng. 114:133-137. 
Wang, J. C., R. N. Wu, W. Y. Zhang, Z. H. Sun, W. J. Zhao, and H. P. Zhang. 2013. Proteomic comparison of the probiotic bacterium Lactobacillus casei Zhang cultivated in milk and soy milk. J. Dairy Sci. 96:5603-5624.

Yamamoto, N., A. Akino, and T. Takano. 1994. Antihypertensive effect of the peptides derived from casein by an extracellular proteinase from Lactobacillus helveticus CP79. J. Dairy Sci. 77:917-922.

Yamamoto, N., M. Maeno, and T. Takano. 1999. Purification and characterization of an antihypertensive peptide from a yogurt-like product fermented by Lactobacillus helveticus CPN4. J. Dairy Sci. 82:1388-1393.

Yuan, J., L. Zhu, X. Liu, T. Li, Y. Zhang, T. Ying, B. Wang, J. Wang, H. Dong, and E. Feng. 2006. A proteome reference map and proteomic analysis of Bifidobacterium longum NCC2705. Mol. Cell. Proteomics 5:1105-1118.
Zhang, F. M., Z. Li, Z. Liu, L. L. Liu, W. Tian, D. W. Jin, M. S. Li, K. Yang, and Y. M. Han. 2013. The studies on the preparation of antihypertensive peptides of yak milk casein fermentation with Lactobacillus helveticus. J. Northwest University for Nationalities 34:64-71.

Zhang, W. Y., Y. F. Chen, W. J. Zhao, L. Y. Kwok, and H. P. Zhang. 2014. Gene expression of proteolytic system of Lactobacillus helveticus $\mathrm{H} 9$ during milk fermentation. Ann. Microbiol. http:// dx.doi.org/10.1007/s13213-014-0902-3.

Zhao, W., Y. Chen, Z. Sun, J. Wang, Z. Zhou, T. Sun, L. Wang, W. Chen, and H. Zhang. 2011. Complete genome sequence of Lactobacillus helveticus H10. J. Bacteriol. 193:2666-2667. 